\title{
JURNAL MANAJEMEN BISNIS DAN KEWIRAUSAHAAN
}

Terbit enam kali dalam setahun. Berisi tulisan yang diangkat dari hasil penelitian di bidang Ilmu Manajemen dan Kewirausahaan.

\section{Ketua Dewan Penyunting}

Prof. Ir. Carunia Mulya Firdausy, MA, Ph.D - Universitas Tarumanagara

\section{Wakil Ketua Dewan Penyunting}

Dr. Eko Harry Susanto - Universitas Tarumanagara

\author{
Anggota Dewan Penyunting \\ Dr. Ir. Agus Zainul Arifin, MM - Universitas Tarumanagara \\ Dr. Eddy Supriyatna MZ, M.HUM - Universitas Tarumanagara \\ Dr. Anas Lutfi, MM, MKN - Universitas Indonesia \\ Dr. Hardius Usman, M.Si - Universitas Indonesia \\ Dr. Indra Widjaja, SE, MM - Universitas Tarumanagara \\ Dr. Hetty Karunia Tunjungsari - Universitas Tarumanagara
}

\author{
Sekretariat \\ Maria Benedicta, SE \\ Margaretha Hillary, S.Ds, MM
}

Alamat Penyunting dan Tata Usaha: Program Studi MM Untar, Kampus 1, Gedung Utama, Lantai 14, Jl. Letjen. S. Parman No. 1 Grogol, Jakarta 11440. Telp. (62-21) 565-5806 dan Fax. (62-21) 565-5808. Email: mm@untar.ac.id 


\section{JURNAL MANAJEMEN BISNIS \& KEWIRAUSAHAAN}

September 2017, Volume 1, No. 1

e-ISSN 2598-0289

Halaman 1-154

Pengaruh Employee Engagement dan Work Life Balance terhadap

01-07

Turn Over Intention di Generasi Millenial

Lita Chrisdiana \& Mukti Rahardjo

Analisis Kualitas Pelayanan pada Restoran XYZ dalam

08-16

Rangka Mengukur Kepuasan Pelanggan

Stella, Eko Harry Susanto

Pengaruh LMX dan Teamwork terhadap Kinerja Karyawan di PT XYZ

Donny Sutanto Tan, Eko Harry Susanto

Analisis Pengukuran Kinerja Perusahaan PT XYZ dengan

26-32

Menggunakan Metode Balanced Scorecard

Yakobus Teofilus, Anas Lutfi

Pengaruh Website Quality terhadap Perceived Trust dan Dampaknya

pada Repurchase Intention pada Website Matahari Mall

Freddy Sudiyono, Chairy

Pengaruh DER, Firm Size, NPM, EPS, ROE, dan EVA terhadap Nilai Perusahaan pada

Perusahaan Sektor Properti dan Real Estate yang Terdaftar di BEI Periode 2011-2015

Karina Juwita

Analisis Citra Merek, Kualitas Produk, dan Bauran Promosi Efeknya

49-57

terhadap Keputusan Pembelian Pasta Gigi Pepsodent

(Studi Kasus di Perumahan Ciledug Indah 2 Periode Maret - Mei 2015)

Priscilla Loekman, Chairy

Analisa Pengaruh Atmosfer Toko terhadap Perilaku Belanja Konsumen

pada Gerai Farmers Market Area Jakarta Utara

Putri Hardiyanti

Faktor-faktor yang Mempengaruhi Pengungkapan Tanggung Jawab Sosial Perusahaan

Posisi Daya Saing Perusahaan Taksi Blue Bird pada Era Teknologi Disruptif

70-76

Victor Agustinus

Analisis Pengaruh Faktor-faktor Fundamental terhadap Harga Saham

77-84

pada Perusahaan Manufaktur di Bursa Efek Indonesia (BEI)

Dermawan Wijaya

Pengaruh Gender, Gaya Kepemimpinan dan Budaya Organisasi terhadap Kinerja Karyawan (Studi Kasus pada PT XYZ)

lenia Nur Soelistyoningrum

Analisa Semiotik Denotasi, Konotasi dan Mitos Iklan Indomie Versi 45th Anniversary di Televisi Andriyanto

Pengaruh PDB, Inflasi, Tingkat Suku Bunga dan Nilai Tukar Rupiah terhadap Indeks Harga Saham JAKPROP yang Terdaftar di Bursa Efek Indonesia

100-107 Chendra Gunawan, Carunia Mulya Firdausy

Faktor yang Mempengaruhi Penetapan Hotel $X$ sebagai Wedding Venue 
Analisis IFE, EFE, dan Balance Scorecard pada Grup Perusahaan PT Kirana Megatara

Pengaruh Waktu Tunggu, Harga dan Kualitas Pelayanan terhadap Kepuasan Konsumen

$125-132$ pada Maskapai XYZ Terminal 1B di Bandara Soekarno Hatta Seri Warsih

Nilai Pasar, Aset Tetap, Profitabilitas, Struktur Modal dan Nilai Perusahaan

$133-140$ pada Perusahaan yang Melakukan IPO di Tahun 2013

Matilda

Analisis Pengaruh Mekanisme Good Corporate Governance, Leverage, dan Ukuran

$141-149$

Perusahaan terhadap Tindakan Manajemen Laba pada Perusahaan Manufaktur yang

Terdaftar di Bursa Efek Indonesia Tahun 2014-2016

Selviani, Indra Widjaja

Pengaruh Service Quality dan Staff Behaviour terhadap Brand Loyalty TIKI di Jakarta Utara:

$150-154$

Customer Satisfaction sebagai Variabel Mediasi

Rendy Surya 